\title{
CORN PRODUCTIVITY IN FUNCTION OF SURFACE APPLICATION OF LIME IN DIFFERENTS MANAGEMENT SYSTEMS AND CULTURAL PREPARATION
}

\author{
KAREM C. P. NARIMATSU ${ }^{1}$, LUIZ M. M. DE MELLO ${ }^{2}$, LUIS A. DA SILVA \\ DOMINGUES ${ }^{3}$, CARLOS A. CHIODEROLI ${ }^{4}$, RONALDO C. LIMA ${ }^{5}$
}

\begin{abstract}
The evaluation of technologies employed at the agricultural production system such as crop rotation and soil preparation, both associated with crop-livestock integration, is crucial. Therefore, the aim of the present study was to evaluate the incorporation of lime for three no-tillage systems and cultural managements in system of crop-livestock integration, with emphasis on corn grain yield. The experiment was conducted from January 2003 to April 2005 at Selvíria city, MS, in Dystroferric Red Latosol, clay texture. The experimental design was randomized blocks with split plots consisted of three main treatments, aimed the soil physics conditioning and the incorporation of lime: PD - No-no-tillage; CM - minimum no-tillage, and PC - conventional no-tillage; and of two secondary treatments related to the management: rotation and crop succession, with four replications. Data on agronomic traits of maize were analyzed: plant height, stem diameter, height of the first spike insertion, 100 grains weight and grain yield. The results showed that the maize produced under the system of croplivestock integration is quite feasible, showing that grain yields are comparable to averages in the region and the different soil physical conditioning and incorporation of lime did not influence the corn yield as well as the cultural managements, rotation and succession, did not affect the maize crop behavior after two years of cultivation.
\end{abstract}

KEYWORDS: no tillage system, minimum tillage, conventional tillage, crop-livestock integration, crop rotation.

\section{PRODUTIVIDADE DE MILHO EM FUNÇÃO DA APLICAÇÃO SUPERFICIAL DE CALCÁRIO EM DIFERENTES SISTEMAS DE PREPARO E MANEJO CULTURAL}

RESUMO: A avaliação das tecnologias empregadas ao sistema de produção agrícola, tais como rotação de culturas e preparo de solo, ambos associados à integração lavoura-pecuária, é importante para tomadas de decisões futuras. Portanto, objetivou-se, no presente trabalho, avaliar a incorporação de calcário por três sistemas de preparo do solo e dois manejos culturais, em sistema de integração lavoura-pecuária, com ênfase para produtividade de grãos de milho. O experimento foi conduzido no período compreendido de janeiro de 2003 a abril de 2005, no município de Selvíria-MS, em Latossolo Vermelho distroférrico, textura argilosa. O delineamento experimental adotado foi o de blocos ao acaso, com parcelas subdivididas, constituídas por três tratamentos principais, visando o condicionamento físico do solo e a incorporação de calcário: PD - Plantio Direto; CM - Cultivo Mínimo, e PC - Preparo Convencional; e por dois tratamentos secundários, relacionados ao manejo: rotação e sucessão de culturas, com quatro repetições. As características agronômicas do milho analisadas foram: altura de planta, diâmetro de colmo, altura de inserção da primeira espiga, massa de 100 grãos e produtividade de grãos. Os resultados mostraram que não houve diferenças estatísticas na produtividade do milho, tanto em função dos tratamentos de manejo do solo para incorporação de calcário, como nos manejos culturais, rotação e sucessão, após dois anos de cultivo.

PALAVRAS CHAVE: sistema plantio direto, cultivo mínimo, preparo convencional, integração lavoura-pecuária, rotação de culturas.

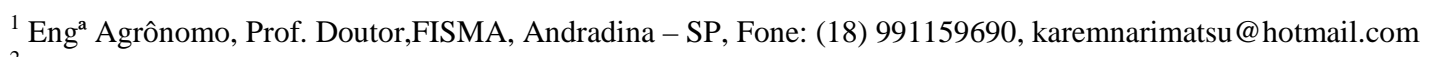

${ }^{2}$ Eng $^{\circ}$ Agrônomo, Prof. Doutor, DEFERS, FE-UNESP/Ilha Solteira-SP-malcolm@agr.feis.unesp.br

${ }^{3}$ Eng $^{\circ}$ Agrônomo, Prof. Doutor, UFU/Uberlândia-MG, luisdom@ig.com.br

${ }^{4}$ Eng $^{\circ}$ Agrônomo, Prof. Doutor, DENA, UFC/Fortaleza -CE, ca.chioderoli@ufc.br

${ }^{5}$ Engo Agrônomo, Prof. Doutor, Unesp-Dracena-SP- rclima@dracena.unesp.br

Recebido pelo Conselho Editorial em: 27-9-2011

Aprovado pelo Conselho Editorial em: 25-11-2013
} 


\section{INTRODUCTION}

Soil management and the use of innovative technologies are essential tools for sustainability of the production system, aiming to reduce costs and adding value to products, which can be achieved with the integration of crops and livestock (ILP), tillage systems and conditioning physical and chemical soil providing gains to producers, especially in the savannah regions (LANDERS, 2007) .

Corn is one of most produced cereals in Brazil, grown on about 14.8 million hectares, with production of approximately 57 million tons of grain and average yield of $4.156 \mathrm{~kg} \mathrm{ha}^{-1}$ in the 2010/11 season (CONAB, 2011). Due to this importance, it is critical, in the production system of high-tech, the knowledge of soil management, tillage and physical corrections as unzipping soil and chemical, in order to make the system sustainable, and promote increased productivity, decreased costs and environmental risks.

Surface liming, if necessary, should be performed prior to implantation of cultures and due to the low solubility of limestone, neutralizing its action depends on the contact surface and the reaction time with the soil. Therefore, the different forms of tillage, aiming to incorporate or not surface applied lime, may influence the duration and intensity of reaction and consequently in the agronomic characteristics of the crop. The soil tillage can also influence the growth of plants because of the change aeration in the resistance to root penetration, and consequently the absorption of water and nutrients (MOSADDEGHI et al., 2009).

According to PETERSEN (2008), soil turn positively influences the rate of initial root growth and crop performance; the management can also affect the distribution of roots in the soil profile (MOTTA et al., 2006).

Minimum tillage and tillage (SPD) promote minimum soil mobilization, making the reaction of limestone and availability of nutrients slower and may not interfere with crop productivity in the ILP system.

SPD and crop-livestock integration are management alternatives that combine the maintenance and even increase productivity with greater rationality of the feedstock used (SANTOS et al., 2008). Thus, one must know the plant species to be used in the rotation program for their dry matter production and decomposition time, which interferes on soil chemical, including CTC attributes that directly affects the dynamics of cations (ANDREOTTI et al., 2008).

Crop rotation is one way to prevent the problem of compression in the SPD, with the use of cover crops that have characteristics of hardiness and vigorous root system (MUZILLI, 2006). In addition to improving the physical and chemical properties of soil, provided by crop rotation, can also promote increased productivity. CUNHA et al. (2007) observed that the association of soy/ brachiaria contributed to the stability of aggregates, showing the importance of crop rotation with grasses and leguminous crops in the productive environment.

It is worth to mention the importance of evaluating the system as a whole, with a succession planning / crop rotation adequate to ensure the sustainability of the SPD and integrating systems involving crop and livestock (PARIZ et al., 2009). According to ALLEN et al. (2007) and FRANZLUEBBERS (2007), the results of this system reflect advances in the aspects of technology, management, productivity, and increasing profitability.

However, despite the technological advances and the implementation of sustainable farming systems such as SPD and ILP is still common unfamiliarity, by the producer, of which benefits actual crop rotation and soil management can provide (FIGUEIREDO et al., 2009).

Given the above, the study aimed to assess the incorporation of limestone for three tillage systems and cultural management strategies in crop-livestock integration, with emphasis on grain yield corn system. 


\section{MATERIALS AND METHODS}

The experiment was conducted from January 2003 to April 2005, under field conditions, in the Farm Teaching and Research UNESP, Ilha Solteira, Brazil, located in the geodesic coordinated $20^{\circ} 18^{\prime}$ S e $52^{\circ} 40^{\prime}$ W, with an average altitude of $340 \mathrm{~m}$. The climate, according to Köeppen, is humid and tropical, with rainy season in summer and dry in winter, the fundamental type Aw and average annual rainfall of $1,370 \mathrm{~mm}$. Figure 1 presents the data of rainfall and temperature in the period of the experiment.

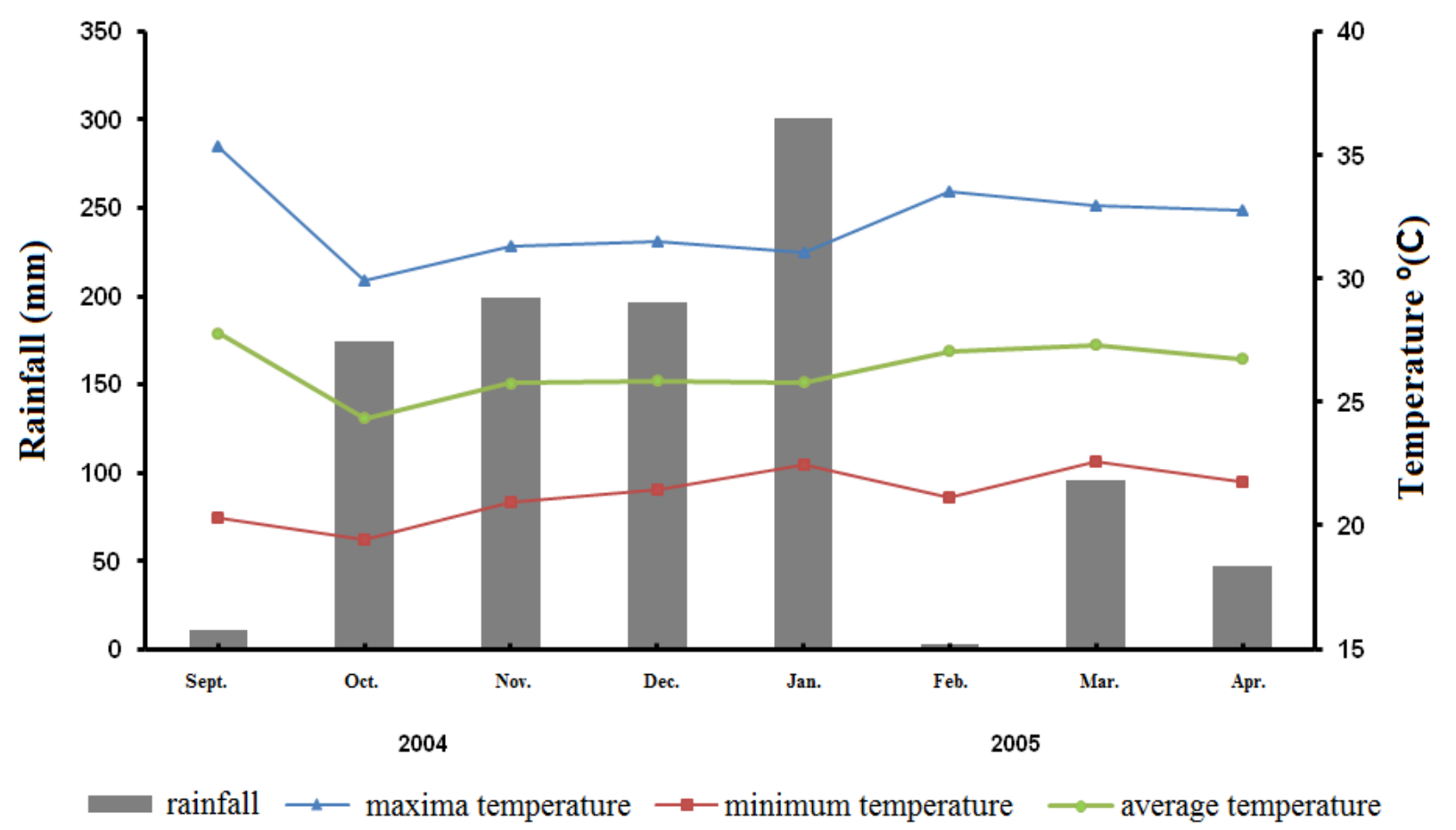

FIGURE 1. Rainfall (mm) and average of maximum, minimum and mean temperature $\left({ }^{\circ} \mathrm{C}\right)$, during the experiment (Selvíria - MS, Brazil, crop year 2004/2005).

The experimental area originally presented the savannah vegetation that was cleared in 1977 and installed Brachiaria decumbens. In 1990 it was replaced by Brachiaria brizantha on which the experiment with corn and soybeans was installed. The experimental area was classified as Distroferric Red Latossol clayey (EMBRAPA, 2006), with initial chemical characteristics (samples taken in November 2002) described in Table 1.

TABLE 1. Soil chemical characterization of experimental area at depths of $0,0-0,10 \mathrm{~m} ; 0,10-0,20$ to $0,20-0,30 \mathrm{~m}$.

\begin{tabular}{|c|c|c|c|c|c|c|c|c|c|c|c|c|}
\hline $\begin{array}{l}\text { Depth } \\
\text { (m) }\end{array}$ & $\begin{array}{l}\text { P resin } \\
\mathrm{mg} \mathrm{dm}^{-3}\end{array}$ & $\begin{array}{l}\text { M. O. } \\
\mathrm{g} \mathrm{dm}^{-3}\end{array}$ & $\begin{array}{c}\mathrm{pH} \\
\mathrm{CaCl}_{2}\end{array}$ & $\mathrm{~K}$ & $\mathrm{Ca}$ & $\mathrm{Mg}$ & $\begin{array}{l}\mathrm{H}+\mathrm{Al} \\
-\mathrm{mmol}\end{array}$ & $\mathrm{Al}$ & SB & CTC & $\begin{array}{l}\mathrm{V} \\
\%\end{array}$ & $\begin{array}{l}\mathrm{m} \\
\%\end{array}$ \\
\hline $0.0-0.10$ & 6.0 & 40.0 & 5.3 & 1.0 & 31.0 & 25.0 & 31.0 & 0.0 & 54.0 & 85.0 & 63.0 & 0.0 \\
\hline $0.10-0.20$ & 5.0 & 32.0 & 4.7 & 0.7 & 19.0 & 9.0 & 40.0 & 2.0 & 30.0 & 70.0 & 42.0 & 2.8 \\
\hline $0.20-0.40$ & 4.0 & 21.0 & 4.5 & 0.7 & 10.0 & 4.0 & 37.0 & 4.0 & 15.0 & 52.0 & 29.0 & 7.7 \\
\hline
\end{tabular}

The experimental design was randomized blocks with split plots, consisting of three main treatments targeting the fitness of the soil and limestone material incorporation: PD - tillage, CM Minimum Cultivation, and PC - Conventional No-tillage, and two secondary treatments related to the management: rotation and succession planting, with four replications. 
Each sub-plot consisted of $810 \mathrm{~m}^{2}(4.5 \mathrm{~m} \mathrm{x} 180 \mathrm{~m})$ and used as floor area 9 rows of $4 \mathrm{~m}$, spaced at $0.90 \mathrm{~m}\left(32.4 \mathrm{~m}^{2}\right)$. Thus, the total area of the experiment was 1.94 ha. An analysis of variance by $F$ test $(p \leq 0.05)$ and, subsequently, the comparison of average by Tukey test $(p \leq 0.05)$.

Thus, in February 2003 was used $1.7 \mathrm{t} \mathrm{ha}^{-1}$ of dolomite limestone (PRNT 80) for correction of soil acidity, according to the initial chemical analysis (Table 1), aiming to high base saturation to $70 \%$, according of the equation RAJ et al. (1996) in depth from 0.0 to $0.20 \mathrm{~m}$.

The limestone was released by trailer distributor volumetric metering mechanism and centrifugal applicator on Brachiaria pasture and then deployed the main treatments: where PD - notillage (limestone on the soil surface without incorporation); CM - Cultivation Low (limestone material incorporation using a chisel plow $0.25 \mathrm{~m}$ ) and PC - Conventional No-tillage (incorporation of limestone with heavy grade, $0.18 \mathrm{~m}$ followed by light disking).

After these treatments the area remained at resting until October 2003, when sowing soybean and corn was performed. After harvest, the area remained at rest so that there was restoring brachiaria through the seed bank and the remaining plants. In 2004/05 crop year, they were subdivided for the combination of maize sowing in SPD within the managements and succession of culture, rotation of crops, preserving the principal, that is, PD, CM and PC treatments. The subdivision of the plots, according to management, was the crop rotation (maize sowing in the subplot where there was soybean) and succession of crops (maize sowing in the subplot where there was corn crop).

The following agricultural equipment were used: tractor tire $(4 \times 2)$ with a power of $54.4 \mathrm{~kW}$ engine, and 3,951 kg mass in running order; tractor tire $(4 \mathrm{x} 2)$, with a power of $59.6 \mathrm{~kW}$ engine, and mass of $4,320 \mathrm{~kg}$ in running order; tractor tire (4x2 TDA), with power of $110.2 \mathrm{~kW}$ engine, and $8,175 \mathrm{~kg}$ mass in running order and distributor of solid fertilizer spread, with distribution range $6 \mathrm{~m}$. Table 1 presents other equipment used for this survey.

TABLE 2. Characteristics of the equipment used.

\begin{tabular}{cccccc}
\hline Equipment & Spray & $\begin{array}{c}\text { Grid } \\
\text { Super Heavy }\end{array}$ & $\begin{array}{c}\text { Grid } \\
\text { Light }\end{array}$ & Scarifier & $\begin{array}{c}\text { Seeder- } \\
\text { Fertilizer Machine }\end{array}$ \\
\hline $\begin{array}{c}\text { brand / } \\
\text { model }\end{array}$ & $\begin{array}{c}\text { Jacto/ } \\
\text { PJ - 600 }\end{array}$ & Marchesan- TatuMarchesan- Tatu & $\begin{array}{c}\text { Jumbo Mati } \\
\text { JMHD-7 }\end{array}$ & $\begin{array}{c}\text { Marchesan/Cop } \\
\text { Suprema }\end{array}$ \\
\hline assets & 24 Tips & 14 disks & 28 disks & $\begin{array}{c}7 \text { rods, roll to } \\
\text { break clod }\end{array}$ & $\begin{array}{c}\text { 4 rows with } \\
\text { stem scrapers }\end{array}$ \\
& $\begin{array}{c}110-02 \\
\text { spaced } \\
\text { per } 0.5 \mathrm{~m}\end{array}$ & $32^{\prime \prime}$ & 20 & & \\
\hline
\end{tabular}

For the drying area $1.8 \mathrm{~kg} \mathrm{ha}^{-1}$ of glyphosate (i.a) $+0.860 \mathrm{~kg} \mathrm{ha}^{-1}$ of $2.4-\mathrm{D}$ was used in total area. In the pre-emergence control $1.5 \mathrm{~kg} \mathrm{ha}^{-1}$ were used Atrazine $+1.16 \mathrm{~kg} \mathrm{ha}^{-1} \mathrm{~S}$-metolachlor (i.a) applied at sowing day.

The hybrid used was the DEKALB-466, early, fit for the region, with spacing of $0.90 \mathrm{~m}$, between rows, targeting population of 65,000 plants $\mathrm{ha}^{-1}$. For the treatment of seeds $0.6 \mathrm{~kg}$ ha- 1 thiodicarb (i.a) was used per $100 \mathrm{~kg}$ of seed. In maize sowing (26/11/2004) was used as base fertilizer, $300 \mathrm{~kg} \mathrm{ha}^{-1}$ of commercial formula (08-28-16). Two fertilizers application were performed; the first on 20/12/2004 at phenological stage V4, using $333 \mathrm{~kg} \mathrm{ha}^{-1}$ of formula (31-0018) fertilizer applications in coverage while driven culture, and the second application were held on 08/01/2005, at the phenological stage V7, using $113 \mathrm{~kg} \mathrm{ha}^{-1}$ of urea.

Application was made with $0.172 \mathrm{~kg} \mathrm{ha}^{-1}$ of Methomy (i.a) at 22 days after sowing corn, and other application with $0.015 \mathrm{~kg} \mathrm{ha}^{-1}$ of Lufenuron (i.a) 39 days after sowing for the control of Spodoptera frugiperda. 
Data from agronomic characteristics of maize were analyzed: plant height, stem diameter, height of first spike insertion, weight of 100 grains and grain production. The evaluation of the initial population of maize plants was performed after stabilization of the emergency eight days after sowing, and the final population of corn plants was evaluated by counting the number of plants contained in the useful area of each sub-portion. These values were converted to plants per hectare. The percentage of survival of maize plants was determined by the ratio of the final population and initial plant population, multiplied by the factor 100 .

Plant height is determined at the end of the crop cycle, measuring the space between the soil surface and the apex of floral tassel, 10 plants of each subplot, as well as height of the first spike insertion, determined by measuring the distance between the ground surface and the first insertion spike present in the plant. The values of average stem diameter were observed by digital pachymeter, measured in the basal region of the stem in 10 plants from each sub-plot.

The weight of 100 seeds was determined by withdrawing samples harvested and threshed grain in each sub-portion. A total of 100 grains were separated manually and counted, forming eight repetitions for each sub-plot, and weighed on an electronic balance accurate to $0.01 \mathrm{~g}$ and subsequently corrected for moisture content of $13 \%$, according to the methodology adapted from BRAZIL (1992). Grain yield of maize was obtained by manual collection of all spikes floor area of each subplot, which is mechanically threshed and separated grain weighed for determination of water content. After, the correction of the grain mass to the extent of $13 \%$ humidity, which were converted into $\mathrm{kg} \mathrm{ha}^{-1}$.

\section{RESULTS AND DISCUSSION}

Observing Table 3, there is no significant difference of the variables initial and final populations and survival percentage of maize plants, the physical conditioning of the soil and cultural management treatments. The incorporation of limestone did not affect these attributes, because the soil showed the minimum development of plants in all treatment conditions.

TABLE 3. Average values of initial population, final population survival percentage of corn plants, depending on the soil physical conditioning and cultural management (crop rotation and succession).

\begin{tabular}{ccccc}
\hline \multirow{2}{*}{ Treatments } & & \multicolumn{2}{c}{ Population (plants ha ${ }^{-1}$ ) } & \% Survival \\
\cline { 3 - 5 } & & Inicial & Final & (\%) \\
\hline \multirow{2}{*}{ Conditionings } & PD & $65.450 \mathrm{a}$ & $62.800 \mathrm{a}$ & $96.01 \mathrm{a}$ \\
Physicalof the soil (C) & CM & $63.462 \mathrm{a}$ & $60.838 \mathrm{a}$ & $95.98 \mathrm{a}$ \\
& PC & $62.150 \mathrm{a}$ & $60.412 \mathrm{a}$ & $97.24 \mathrm{a}$ \\
\hline Cultural & Succession & $64.217 \mathrm{a}$ & $62.417 \mathrm{a}$ & $95.50 \mathrm{a}$ \\
Management (M) & rotation & $63.159 \mathrm{a}$ & $60.283 \mathrm{a}$ & $97.27 \mathrm{a}$ \\
\hline \multirow{2}{*}{ F Values } & $\mathrm{C}$ & 0.40 & 0.58 & 0.52 \\
& $\mathrm{M}$ & 0.57 & 1.71 & 0.32 \\
CV $(\%)$ & $\mathrm{C} \mathrm{x} \mathrm{M}$ & 0.24 & 0.06 & 0.71 \\
\hline
\end{tabular}

Means followed by the same letter in columns do not differ by Tukey test at 5\% probability. PD- no-tillage; CM - Minimum Cultivation, and PC - Conventional No-tillage.

Despite of the initial population did not differ statistically; their values were close to the desired population, 65,000 plants $\mathrm{ha}^{-1}$. This decrease, although it has not been studied, can be explained by some adversity, especially by slip on the planter wheels in treatments with tillage. These results corroborate with those found by CRUZ et al. (2009) that working with the cultivation of maize, single and intercropped with Brachiaria decumbens in tillage systems: conventional (double plow and double disking), minimum tillage (one plowing and one disking) and no-tillage (no soil mixing ), no significant differences in plant population was found. 
In the same sense, KANEKO et al. (2010), working with three different soil tillage (disk harrow + leveling harrow, chisel plow + disc harrows and no-tillage), five epochs of $\mathrm{N}$ application and two spacing $(0.45$ and $0.90 \mathrm{~m})$, found that soil management in no-tillage system promoted higher plant population. The same results were found by ARF et al. (2007), who in two seasons of cultivation, no-tillage system provided higher plant population, working with the spacing of $0.90 \mathrm{~m}$. According to the authors the most friction between the seeder in no-tillage and the driving wheel , enabled the better functioning of the system, thus increasing the number of seeds per meter, and consequently the plant population. Another factor that may have supported this is the fact that the no-tillage displays greater moisture retention in the soil, but this attribute was not measured. Also BINOTTI et al. (2007), working with methods of tillage equal to this work in the same area, found positive effect of no-tillage on plant population of winter beans variety.

It was found that for values of plant height, the applied treatments had no significant effect (Table 4). The same results were found by DEMÉTRIO et al. (2008), in which plant height was not affected by changes at spaced, showing do not have occurred intraspecific competition. However, for insertion height of the $1^{\text {st }}$ spike and stem diameter, there was a significant difference at $5 \%$ probability by Tukey test, on physical fitness factor of the soil.

TABLE 4. Mean values of corn agronomic traits, depending on the soil physical conditioning and cultural management.

\begin{tabular}{ccccc}
\hline \multirow{2}{*}{ Treatments } & & \multicolumn{2}{c}{ Height (m) } & \multirow{2}{*}{$\begin{array}{c}\text { Diameter } \\
\text { of the Stem (mm) }\end{array}$} \\
\cline { 3 - 4 } & & Plants & Insert $1^{\text {st }}$ spike & $21.10 \mathrm{~b}$ \\
Conditionings physical & PD & $2.62 \mathrm{a}$ & $1.24 \mathrm{~b}$ & $21.60 \mathrm{ab}$ \\
of the soil & $\mathrm{CM}$ & $2.60 \mathrm{a}$ & $1.49 \mathrm{a}$ & $22.90 \mathrm{a}$ \\
(C) & PC & $2.69 \mathrm{a}$ & $1.28 \mathrm{~b}$ & $21.90 \mathrm{a}$ \\
Management & Sucessão & $2.64 \mathrm{a}$ & $1.35 \mathrm{a}$ & $21.80 \mathrm{a}$ \\
cultural (M) & Rotação & $2.60 \mathrm{a}$ & $1.32 \mathrm{a}$ & $6.71^{*}$ \\
\hline \multirow{2}{*}{ F values } & $\mathrm{C}$ & 0.95 & $1.27^{*}$ & 0.19 \\
& $\mathrm{M}$ & 0.39 & 3.32 & 0.50 \\
\hline $\mathrm{CV}(\%)$ & $\mathrm{C} \mathrm{x} \mathrm{M}$ & 0.25 & 0.70 & 5.17 \\
\hline
\end{tabular}

Averages followed by the same letter in columns do not differ by Tukey test at 5\% probability. PD - no-tillage, CM - Minimum cultivation, and PC - Conventional No-tillage. * - Significant at 5\% probability by F test

For physical conditioning CM, the insertion height of $1^{\text {st }}$ spike was higher, whereas the PC -PD did not differ. For the values of stem diameter, physical conditioning PC and PD showed higher and lower value, respectively. This behavior often is linked to phenotypic characteristics of the hybrid, which can be changed due to local climatic conditions, incidence of pests and diseases, and also for crop management and tillage system adopted. Therefore, the determination of these agronomic traits is of utmost importance to verify whether they are related or not with the grain yield.

FARINELLI \& LEMOS (2010) found that different doses of nitrogen, grown under conventional no-tillage and SPD system using succession of black oat /corn, showed no significant differences for the values of insertion height of first spike and stalk diameter, contrary to the results found in this research. The values of stem diameter and height of insertion of first spike increased with soil tillage because, according to PETERSEN (2008), the soil tillage positively influences the rate of initial root growth and crop performance, and management adopted can also affect the distribution of roots in the soil profile (MOTTA et al., 2006).

The values of the physical fitness of soil and crop management treatments were not significantly different at the 5\% level of probability for 100 grain mass and grain yield (Table 5). 
TABLE 5. Average values of grain yield and 100 corn grains weight, according to the soil physical conditioning and cultural management.

\begin{tabular}{cccc}
\hline \multirow{2}{*}{ Treatments } & & Grain Production & Weight of 100 grains \\
\cline { 2 - 4 } & & $\left(\mathrm{kg} \mathrm{ha}^{-1}\right)$ & $(\mathrm{g})$ \\
\hline \multirow{2}{*}{ Conditionings } & PD & $4.659 \mathrm{a}$ & $23.70 \mathrm{a}$ \\
physical of the soil (C) & $\mathrm{CM}$ & $5.148 \mathrm{a}$ & $24.02 \mathrm{a}$ \\
& PC & $5.412 \mathrm{a}$ & $24.03 \mathrm{a}$ \\
\hline Management cultural & Succession of & $5.142 \mathrm{a}$ & $24.04 \mathrm{a}$ \\
$(\mathrm{M})$ & Rotation & $5.005 \mathrm{a}$ & $23.79 \mathrm{a}$ \\
\hline \multirow{2}{*}{ F values } & $\mathrm{C}$ & 3.42 & 0.29 \\
& $\mathrm{M}$ & 0.34 & 0.35 \\
\hline CV (\%) & $\mathrm{C} \mathrm{x} \mathrm{M}$ & 0.93 & 0.05 \\
\hline Av & & 11.26 & 4.38 \\
\hline
\end{tabular}

Averages followed by the same letter in columns do not differ to the Tukey test at 5\% probability. PD - no-tillage; CM - Minimum Cultivation, and PC - Conventional No-tillage.

This was probably due to the rearrangement of soil structures of CM and PC treatments, being the second year of cultivation, and also by infiltration of limestone by canaliculated formed by the decomposition of root crops in succession and rotation, allowing reaction of neutrality of limestone in the subsurface. However, DOMINGUES (2004), under study in the same experimental area (crop year 2003/04), showed higher values for grain yield in minimum and conventional no-tillage, and lower values in areas SPD. For mass of 100 grains, this author finds highest value in minimum tillage and lower value for treatment without tillage. In research conducted by SANTOS et al. (2006) in a dystrophic Nitosol, applied magnesium thermophosphate ,thermophosphate + lime and thermophosphate + gypsum + stillage , cultivated in systems no-tillage and conventional no-tillage, was found that conventional no-tillage gave higher grain yield of maize compared to the system notillage, agreeing with the results found by DOMINGUES (2004).

ALMEIDA et al. (2008) found, after three years of installation of soil management systems, the effects of rotation with green manure, corn or soybean (summer) and beans "winter", that systems of crop rotation, cover crops and management of the soil influence the physical and chemical properties of soil and crop productivity bean, corn and soybeans. Similar results were found by CRUZ et al. (2009), obtaining better chemical soil conditions and higher grain yield of corn in minimum tillage and no-tillage systems.

Although grain yield did not differ statistically between the different soil physical constraints, the PC produced $753.76 \mathrm{~kg}$ more than the PD and $263.91 \mathrm{~kg}$ compared to CM. However, one of the factors that influence was the rainfall. Dry period of 21 days occurred (Figure 1 ) in the reproductive stage, which caused water deficit in culture and thus occurred fall in productivity.

In crop rotation, especially leguminous such as soybeans, one of the most important effects is the utilization of fixed nitrogen, but the nitrogen fertilization performed in all treatments may have masked this effect, not differing significantly from the treatments with rotation.

However, it is also worth highlighting the importance of evaluating the set of techniques adopted, with a succession planning / rotation, tillage appropriate and rational use of agricultural inputs to provide and ensure productivity and increasing profitability. According SULC \& TRACY (2007) and MAUGHAN et al. (2009), there is still need for further research in order to better address the consequences of crop-livestock integration in the socio-economic-environmental complex.

\section{CONCLUSIONS}

The preparation of soil scarification with disc harrow to incorporate limestone and no-tillage without incorporation of limestone, did not differ with regard to corn yield, as well as cultural 
management practices, rotation and succession, also did not affect the behavior of maize farming after two years, in addition to this is recommended that the management of soil no-tillage for being a conservationist and lower economic cost system.

\section{REFERÊNCIAS}

ALLEN, V. G.; BAKER, M. T.; SEGARRA, E.; BROWN, C.P. Integrated irrigated crop-livestock systems in dry climates. Agronomy Journal, Madison, v. 99, n. 2, p. 346-360, 2007.

ALMEIDA, V.P.; ALVEZ, M.C.; SILVA, E.C.; OLIVEIRA, A. Rotação de culturas e propriedades físicas e químicas em Latossolo Vermelho de Cerrado sob preparo convencional e semeadura direta em adoção. Revista Brasileira Ciência Solo, Viçosa-MG, v.32, n.3, p. 1227-1237, 2008.

ANDEROTTI, M.; ARALD, M.; GUIMARÃES, V.F.; JUNIOR, E.F.; BUZETTI, S. Produtividade do milho safrinha e modificações químicas de um latossolo em sistema plantio direto em função de espécie de cobertura após calagem superficial. Acta Scientiarum Agronomy, Maringá, v.30, n.1, p.109-115, 2008.

ARF, O.; FERNANDES, R.N.; BUZETTI, S.; RODRIGUES, R.A.F.; SÁ, M.E.; ANDRADE, J.A.C. Manejo do solo e época de aplicação de nitrogênio no desenvolvimento e rendimento do milho. Acta Scientiarum Agronomy, Maringá, v.29, n. 2, p.211-217, 2007.

BINOTTI, F.F.S.; ROMANINI JUNIOR, A.; ARF, O.; FERNANDES, F.A.; SÁ, M.E.; BUZETTI, S. Manejo do solo e da adubação nitrogenada em feijoeiro de inverno e irrigado. Bragantia, Campinas, v.66, n.1, p.121-129, 2007.

BRASIL. Ministério da Agricultura, do Abastecimento e da Reforma Agrária. Secretaria Nacional de Defesa Agropecuária. Regras para análise de sementes. Brasília, 1992. 365 p.

CONAB - Companhia Nacional de Abastecimento. Levantamento de dados do milho: safra 2010/11. 2011. Disponível em: <http://www.conab.gov.br>. Acesso em: 20 set. 2011.

CRUZ, S.C.S.; PEREIRA, F.R.S.; BICUDO, S.J.; SANTOS, J.R.; ALBUQUERQUE, A.W.; MACHADO, C.G. Consórcio de milho e Brachiaria decumbens em diferentes preparos de solo. Acta Scientiarum Agronomy, Maringá, v.31, n.4, p.663-669, 2009.

CUNHA, E. de Q.; BALBINO, L.C.; STONE, L.F.; LEANDRO, W.M.; OLIVEIRA, G.C. de. Influência de rotações de culturas nas propriedades físico-hídricas de um Latossolo Vermelho em plantio direto. Engenharia Agrícola, Jaboticabal, v.27, n.3, p.665-674, 2007.

DEMÉTRIO, C.S.; FORNASIERI FILHO, D.; CAZETTA, J.O.; CAZETTA, D.A. Desempenho de híbridos de milho submetidos a diferentes espaçamentos e densidades populacionais. Pesquisa Agropecuária Brasileira, Brasília, v.43, n.12, p.1691-1697, 2008.

DOMINGUES, L.A.S. Milho em plantio direto sobre Brachiaria brizantha no sistema integração agricultura-pecuária. 2004. 55 f. Dissertação (Mestrado em Sistemas de Produção) - Faculdade de Engenharia de Ilha Solteira, Universidade Estadual Paulista, Ilha Solteira, 2006.

EMBRAPA .Empresa Brasileira de Pesquisa Agropecuária. Sistema brasileiro de classificação dos solos. 2.ed. Rio de Janeiro: CNPS, 2006. 306 p.

FARINELLI, R.; LEMOS, L.B. Produtividade e eficiência agronômica do milho em função da adubação nitrogenada e manejos do solo. Revista Brasileira de Milho e Sorgo, Sete Lagoas, v.9, n.2, p.135-146, 2010.

FIGUEIREDO, C.C.; SANTOS, G.G.; PEREIRA, S.; NASCIMENTO, J.L.; JÚNIOR, J.A. Propriedades físico-hídricas em Latossolo do Cerrado sob diferentes sistemas de manejo. Revista Brasileira Engenharia Agrícola e Ambiental, Campina Grande, v.13, n.2, p.146-151, 2009.

FRANZLUEBBERS, A. J. Integrated crop-livestock systems in the Southeastern USA. Agronomy Journal, Madison, v. 99, n. 2, p. 361-372, 2007. 
KANEKO, F.H.; ARF, O.; GITTI, D.C.; CHIODEROLI, C.A.; KAPPES, C. Manejo do solo e do nitrogênio em milho cultivado em espaçamentos reduzido e tradicional Bragantia, Campinas, v.69, n.3, p.677-686, 2010.

LANDERS, J. N. Tropical crop-livestock systems in conservation agriculture: the Brazilian experience. Rome: FAO, 2007. 92 p.

MAUGHAN, M.; FLORES, J.P.C.; ANGHINONI, I.; BOLLERO, G.; FERNÁNDEZ, F.G.; TRACY, B.F. Soil Quality and corn yield under crop-livestock integration in Illinois. Agronomy Journal, Madison, v.101, n.6, p.1503-1510, 2009.

MOSADDEGHI, M. R.; MAHBOUBI, A. A.; SAFADOUST, A. Short-term effects of tillage and manure on some soil physical properties and maize root growth in a sandy loam soil in western Iran. Soil \& Tillage Research, Amsterdam, v.104, p.173-179, 2009.

MOTTA, A.C.V.; NICK, J.A.; YORINORI, G.T.; SERRAT, B.M. Distribuição horizontal e vertical da fertilidade do solo e das raízes de cafeeiro (Coffea arábica L.) cultivar Catuaí. Acta Scientiarum Agronomy, Maringá, v.28, n.4, p.455-463, 2006.

MUZILLI, O. Manejo do solo em sistema plantio direto. In: CASÃO JUNIOR, R.; SIQUEIRA, R.; MEHTA, Y. R.; PASSINI, J. J. (Ed.). Sistema plantio direto com qualidade. Londrina; Foz do Iguaçu: IAPAR/ITAIPU Binacional, 2006. cap.2, p.9-27.

PARIZ, C.M.; ANDREOTTI, M.; TARSITANO, M.A.A.; BERGAMASCHINE, A.F.; BUZETTI, S.; CHIODEROLI, C.A. Desempenhos técnicos e econômicos da consorciação de milho com forrageiras dos gêneros Panicum e Brachiaria em sistema de integração lavoura-pecuária. Pesquisa Agropecuária Tropical, Goiânia, v.39, n.4, p.360-370, 2009.

PETERSEN, M. Tillage and root development in corn- Is there a connection?. 2008. Disponível em: $<$ http://www.precisiontillage.com/assets/uploads/tillage_root\%20development\%20article.pdf> Acesso em: 10 maio 2011.

RAIJ, B.van; CANTARELLA, H.; QUAGGIO, J.A.; FURLANI, A.M.C. Recomendções de adubação e calagem para o Estado de São Paulo. 2.ed. Campinas: IAC, 1996. 285 p. (Boletim técnico, 100).

SANTOS, G.G.; SILVEIRA, P.M.; MARCHÃO, R.L.; BECQUER, T.; BALBINO, L.C. Macrofauna edáfica associada a plantas de cobertura em plantio direto em um latossolo vermelho do Cerrado. Pesquisa Agropecuária Brasileira, Brasília, v.43, n.1, p.115-122, 2008.

SANTOS, J.R.; BICUDO, S.J.; ALBUQUERQUE, A.W.; CARDOSO, C.L. Atributos químicos do solo e produtividade do milho afetados por corretivos e manejo do solo. Revista Brasileira de Engenharia Agrícola e Ambiental, Campina Grande, v.10, n.2, p.323-330, 2006.

SULC, R.M.; TRACY, B.F. Integrated Crop-Livestock Systems in the U.S. Corn Belt. Agronomy Journal, Madison, v.99, n.2, p.335-345, 2007. 